\title{
Intrauterine Growth Retardation in Pregnant Women with Long QT Syndrome Treated with Beta-Receptor Blockers
}

\author{
Tatjana Welzel $^{\mathrm{a}} \quad$ Birgit Donner ${ }^{\mathrm{b}} \quad$ Johannes N. van den Anker ${ }^{\mathrm{a}, \mathrm{c}}$ \\ aPediatric Pharmacology and Pharmacometrics, University Children's Hospital of Basel, (UKBB), University of Basel, \\ Basel, Switzerland; bPediatric Cardiology, University Children's Hospital of Basel (UKBB), University of Basel, Basel, \\ Switzerland; 'Division of Clinical Pharmacology, Children's National Hospital, Washington, DC, USA
}

\section{Keywords}

Small for gestational age $\cdot \beta$-receptor blockers - Side effects - Pregnancy · Long QT syndrome

\begin{abstract}
Pregnant women with inherited long QT syndrome (iLQTS) are at an increased risk for preterm delivery and intrauterine growth retardation (IUGR) due to their underlying disease. Additionally, they are at a risk of arrhythmogenic events, particularly during the postpartum period because of physiological changes and increased emotional/physical stress. $\beta$-receptor blockers can effectively prevent life-threatening Torsades de Pointes ventricular tachycardia and they are the treatment of choice in iLQTS. Use of $\beta$-receptor blockers in pregnancy is recommended, although IUGR is commonly reported for prenatally exposed infants. IUGR, particularly in preterm infants, can result in adverse neonatal outcomes. This review was performed to support clinicians in their selection of $\beta$-receptor blocker treatment for their pregnant iLQTS women by (i) summarizing the available literature addressing the impact of different $\beta$-receptor blockers on IUGR and (ii) reporting additional aspects which might influence the $\beta$-receptor blocker selection. In general, experts recom-
\end{abstract}

karger@karger.com www.karger.com/neo

Karger $\stackrel{\text { ' }}{=}$
(C) 2021 The Author(s)

Published by S. Karger AG, Basel

This is an Open Access article licensed under the Creative Common Attribution-NonCommercial-4.0 International License (CC BY-NC) (http://www.karger.com/Services/OpenAccessLicense), applicable to the online version of the article only. Usage and distribution for commercial purposes requires written permission. mend to use nonselective $\beta$-receptor blockers, such as nadolol and propranolol, for iLQTS management as these drugs seem to be superior in effectiveness. However, $\beta$-1-selective receptor blockers, such as bisoprolol or metoprolol, seem to affect less likely uterine contraction, peripheral vasodilation, and are associated with lower IUGR rates and fetal hypoglycemia. They are therefore recommended, except atenolol, as first-line therapy for pregnant women. Additionally, maternal factors such as iLQTS genotype, other underlying comorbidities (e.g., diabetes mellitus type 1, asthma bronchiale), and uteroplacental dysfunction or fetal factors have to be taken into account. Therefore, each woman with iLQTS who wants to become pregnant should be well-advised for a personalized $\beta$-receptor blocker therapy according to the individual risk-benefit evaluation by a multidisciplinary team of cardiologists, gynecologists, pediatric cardiologists, neonatologists, and clinical pharmacologists. During pregnancy, a close monitoring of IUGR and, after birth, monitoring of bradycardia, hypoglycemia, and respiratory depression in the neonate is mandatory. This review summarizes available data on $\beta$-receptor blocker-related risk for IUGR in prenatally

Birgit Donner and Johannes N. van den Anker contributed equally and should therefore be considered as co-senior authors.
Correspondence to:

Tatjana Welzel, tatjana.welzel@ ukbb.ch 
exposed infants and illustrates which factors might influence $\beta$-receptor blocker selection with the aim to support clinicians in their pharmacological management of their pregnant iLQTS patients.

(C) 2021 The Author(s).

Published by S. Karger AG, Basel

\section{Introduction}

Nowadays, an increasing number of women with heart disease, including congenital arrhythmias such as the inherited long QT syndrome (iLQTS), become pregnant [1]. The iLQTS is caused by gene variants coding for ion channels, ion subunits, or regulatory proteins, representing a genetically diverse group of disorders of ventricular repolarization associated with an increased risk of lifethreatening Torsades de Pointes ventricular tachycardias. The 3 major forms of iLQTS are LQTS type 1-3. The diagnosis of iLQTS relies on prolonged QT interval in the electrocardiogram (ECG) or prolongation of the heart beat corrected QT interval (QTc), respectively, clinical and family history, and/or genetic testing [2]. In the absence of secondary causes for QT prolongation, a QTc of $480 \mathrm{~ms}$ or longer in repeated ECGs, or in presence with unexplained syncope, a QTc of $460 \mathrm{~ms}$ or longer indicates iLQTS, or a Schwartz score 1.5-3 shows an intermediate probability of iLQTS $[3,4]$.

It is known that pregnancy in women with heart disease is a medical challenge as the underlying disease is a major risk factor for maternal morbidity and mortality [5], but can also cause fetal complications. Pregnant iLQTS women seem to be at an increased risk of placental or myometrial dysfunction, which might result in stillbirth, miscarriage, preterm delivery, and intrauterine growth retardation (IUGR). Stillbirths are 8 times more frequently reported in iLQTS compared to the normal pregnant population (4 vs. approximately $0.5 \%$ ) and miscarriages are twice more frequent (16 vs. $8 \%$ ) [6]. One reason for intrauterine fetal death might be the risk of iLQTS and bradycardia in the fetus [7], as in $2 / 3$ of newborns from iLQTS mothers/fathers, an iLQTS genotype can be detected [6]. Additionally, the birth weight for newborns of iLQTS mothers seems to be lower if adjusted for gestational age compared to those of iLQTS fathers [6]. It is important to highlight that pregnant iLQTS women themselves are at an increased risk for cardiac events (CE) postpartum, particularly in case of a LQTS type 2 (LQTS2) [8-11]. The mothers have an alternated sleep pattern, lack of sleep, and an increased physical/ emotional stress, which might lead to an increased sym- pathetic activity, with an increased gene-specific CE risk postpartum $[9,11,12]$. The new auditory stimuli of the crying infant might be an additional trigger for $\mathrm{CE}$ in LQTS2 [11]. As estrogen seems to have an anti-arrhythmogenic effect, the physiological estrogen decrease during lactation might be an additional risk factor for CE [13, 14]. During the 9-month postpartum period, a 2.7-fold increased CE risk and a 4.1-fold increased risk for lifethreatening events compared to the preconception period for iLQTS women are reported [10].

The treatment of choice in patients with iLQTS is oral $\beta$-receptor blockers, as they are effective in reducing the $\mathrm{CE}$ risk $[15,16]$. $\beta$-receptor blocker treatment seems to be safe and not teratogenic but is associated with IUGR, apnea, hypoglycemia, hyperbilirubinemia, and bradycardia in the prenatally exposed fetus and newborn infant [1720]. However, bradycardia can be also related with clinical presentation of iLQTS in the newborn [21].

Risk factors for IUGR comprise a wide range and may be caused by fetal (e.g., congenital infection and genetic syndromes), placental (e.g., marginal or velamentous cord insertion, placenta praevia, abruptio placentae, and infarction), and maternal (e.g., smoking, advanced maternal age, very low or very high body mass index, underlying chronic diseases, anemia, and uterine malformation) factors. In pregnant iLQTS women, risk factors for IUGR might include the underlying disease and the $\beta$-receptor blocker treatment. IUGR, particularly in preterm infant can result in adverse neonatal outcome. To our knowledge, no overview about the impact of different $\beta$-receptor blocker on IUGR is available so far. The aim of this review is to summarize available data on $\beta$-receptor blocker-related risk for IUGR and to give an overview in which additional factors might influence $\beta$-blocker selection in pregnant iLQTS patients to support clinicians in their pharmacological management of their pregnant iLQTS patients.

\section{Material and Methods}

Based on a pharmacological clinical consultation, September 19, 2020, a literature review was performed in September 2020 to assess data addressing $\beta$-receptor blocker-related risk for IUGR in infants prenatally exposed to $\beta$-receptor blockers. Search strings in the PubMed database included $\beta$-blocker OR atenolol OR bisoprolol OR metoprolol OR carvedilol OR propranolol OR nadolol AND fetal/intrauterine growth retardation OR small for gestational age. The additional literature addressing efficacy data for $\beta$-receptor blockers in iLQTS that might influence the treatment selection in pregnancy were reviewed. Available full text publications (original articles, case reports, and reviews) were screened. 
Table 1. Former US FDA classification (adapted to [17])

Pregnancy letter categories

A Adequate and well-controlled studies have failed to demonstrate a fetal risk in the first trimester (and there is no evidence of risk in the later trimesters).

B Either animal reproduction studies have not demonstrated a fetal risk but there are no controlled studies in pregnant women, or animal reproduction studies have shown an adverse effect that was not confirmed in controlled studies in women.

C Either study in animals has revealed adverse effects on the fetus and there are no controlled studies in women, or studies in women and animals are not available. Drugs should be given only if potential benefits justify the potential risk to the fetus.

D There is evidence of human fetal risk, but the benefits from use in pregnant women may be acceptable despite the risk (e.g., treatment of life-threatening conditions).

$\mathrm{X} \quad$ Studies in animals or humans have demonstrated fetal abnormalities, there is evidence of fetal risk based on human experience, or both, and the risk of drug use in pregnant women clearly outweighs any possible benefit. The drug is contraindicated in women who are or may become pregnant.

In 2015 the FDA replaced the former pregnancy risk letter categories (A, B, C, D, and X) into the Pregnancy and lactation labeling rule (PLLR). Medications approved prior to June 30, 2001 are not subject to the PLLR rule, while drugs approved on or after June 30, 2001 will be phased in gradually [52]. FDA, Food and Drug Administration.

Additionally, relevant publications were identified manually from the bibliographies of references retrieved from the PubMed search. Data were extracted by a scientist in an electronic datasheet for IUGR. Additional information for the US Food and Drug Administration (FDA) pregnancy letter categories used before June 30, 2015 (Table 1) was retrieved and combined with data from the literature search.

\section{Results}

We could identify 15 papers providing information on the topic IUGR in infants and prenatally exposure to $\beta$-receptor blocker. Of these, 8 cohort studies and 1 case report showed detailed data for IUGR according to prenatally $\beta$-receptor blocker exposure (Table 2). Main indication for the $\beta$-receptor blocker treatment during pregnancy was maternal hypertension. Five reviewed $\beta$-receptor blockers (metoprolol, bisoprolol, carvedilol, propranolol, and nadolol) were classified by the former FDA category (Table 1) as $C$ and atenolol was classified as $\mathrm{D}$. However, the most data available was for atenolol $(n=7)$. Only 1 case report could be identified for nadolol [22]. An important aspect influencing the $\beta$-receptor blocker selection for treatment is the efficacy of the $\beta$-receptor blocker, which seems to depend on the iLQTS genotype. Some studies comparing the efficacy of different $\beta$-blockers in patients with iLQTS are available but randomized controlled trials are lacking.

\section{Data on $\beta$-Receptor Blockers and IUGR in General}

IUGR is reported as a known side effect in the fetus/infant which has been prenatally exposed to $\beta$-receptor blockers, and might be explained by an increase of blood flow resistance in both myometrium and placenta with a decrease in the uteroplacental blood flow [23-26]. Cuneo et al. [6] studied retrospectively 148 pregnancies from 80 LQTS mothers and 23 LQTS fathers, resulting in 118 live births. Of these pregnant females, $71 \%(n=57)$ received $\beta$-receptor blockers. The birth weights of infants from mothers who used $\beta$-receptor blockers $(2.8 \pm 0.7 \mathrm{~kg})$ were significantly different $(p<0.001)$ from the birth weights of infants of LQTS fathers $(3.5 \pm 0.5 \mathrm{~kg})$ and if the birth weights were adjusted for gestational age, infants of LQTS mothers who used $\beta$-receptor blockers had lower birth weights as compared to infants from untreated mothers [6]. It seems that IUGR risk is more pronounced if $\beta$-receptor blocker therapy is started early in pregnancy and continued throughout the entire pregnancy [27]. However,IUGRisalso observedif $\beta$-receptor blockers were only used after the first trimester, but perhaps less severe [28]. As most women with iLQTS will be treated with $\beta$-receptor blockers already before conception the fetus will be exposed during the entire pregnancy. Additionally, the risk for neonatal adverse events seems to increase with high $\beta$-receptor blocker dosages [29].

\section{Data on Different $\beta$-Receptor Blockers and IUGR}

Tanaka et al. [23] analyzed maternal and neonatal outcomes in 158 pregnancies of women with cardiovascular 
Table 2. Current knowledge about $\beta$-receptor blockers and IUGR

\begin{tabular}{|c|c|c|c|c|c|}
\hline $\begin{array}{l}\beta \text {-receptor } \\
\text { blocker }\end{array}$ & Pharmacokinetic properties & Data & $\begin{array}{l}\text { Former } \\
\text { FDA } \\
\text { category } \\
{[17]}\end{array}$ & $\begin{array}{l}\text { Placenta } \\
\text { permeable }\end{array}$ & Additional notes \\
\hline
\end{tabular}

$\beta$-1-receptor selective blockers

\begin{tabular}{|c|c|c|c|c|c|}
\hline Atenolol & $\begin{array}{l}\text { Protein binding: } 6-16 \% \text { [53] } \\
\text { Metabolism: limited hepatic [53] } \\
\text { Elimination half-life: in utero } \\
\text { exposed neonates: } 16 \text { h (mean) } \\
\text { [54], adults: } 6-7 \text { h (longer in case } \\
\text { of renal impairment) [53] }\end{array}$ & $\begin{array}{l}33 \% \text { newborns had IUGR }(n=2 / 6) \text {; atenolol } \\
\text { dose: } 25-50 \mathrm{mg} / \text { day }[23] \\
18 \% \text { of }<2,500 \text { g newborns }(n=115 / 638)[30] \\
3.8 \% \text { of }<1,500 \text { g newborns }(n=24 / 638)[30] \\
48.7 \% \text { of newborns }(n=38 / 78)^{1}[27] \\
\text { Newborns }(n=15) \text { had a lower birthweight } \\
\text { compared to nonexposed newborns }(2,620 \text { vs. } \\
3,530 \text { g; } 910(440-1,380) \text { g, atenolol dose: } 50-200 \\
\text { mg/day, [32] } \\
\text { Exposed newborns were significantly lighter } \\
\text { compared to infants exposed to other } \beta \text {-receptor } \\
\text { blockers [33] } \\
75 \% \text { newborns had IUGR }(n=3 / 4)^{3} \text { [29] } \\
70 \% \text { newborns exposed }<15 \text { weeks gestation } \\
\text { showed growth } \leq 10 \text { th centile }(n=26 / 50) \text { [55] } \\
40 \% \text { newborns exposed }<15 \text { weeks gestation } \\
\text { showed growth }<3 \text { rd centile }(n=15 / 50)[55] \\
51 \% \text { newborns exposed } 15-30 \text { weeks gestation } \\
\text { showed growth } \leq 10 \text { th centile }(n=15 / 29)[55] \\
17 \% \text { newborns exposed } 15-30 \text { weeks gestation } \\
\text { showed growth } \leq 3 \text { th centile }(n=5 / 29)[55]\end{array}$ & $\mathrm{D}$ & Yes $[17,53]$ & $\begin{array}{l}\text { Not recommended in } \\
\text { pregnancy } \\
\text { The highest risk for IUGR } \\
\text { of all analyzed } \beta \text {-receptor } \\
\text { blockers }\end{array}$ \\
\hline Bisoprolol & $\begin{array}{l}\text { Protein binding: } \sim 30 \%[56] \\
\text { Metabolism: extensively hepatic } \\
\text { [56] } \\
\text { Elimination half-life: } 9-12 \mathrm{~h} \\
\text { (normal renal function) }[56]\end{array}$ & $\begin{array}{l}\text { No IUGR was observed }(n=0 / 5) \text {, bisoprolol } \\
\text { dose: } 5-10 \mathrm{mg} / \text { day [23] }\end{array}$ & $\mathrm{C}$ & Yes [17] & $\begin{array}{l}\text { Effective QTc shortening in } \\
\text { LQTS1/LQTS2 [40] } \\
\text { Good long-term tolerance } \\
\text { [40] } \\
\text { Seems similar effective to } \\
\text { nadolol/propranolol in } \\
\text { preventing major CE [39] }\end{array}$ \\
\hline Metoprolol & $\begin{array}{l}\text { Protein binding: } \sim 10-12 \% \text { [57] } \\
\text { Metabolism: extensively hepatic via } \\
\text { CYP2D6 [57] } \\
\text { Elimination half-life: neonates: } \\
\text { 5-10 h, adults: } 3-4 \text { h }(7-9 \text { h in poor } \\
\text { CYP2D6 metabolizers or hepatic } \\
\text { impairment) [57] }\end{array}$ & $\begin{array}{l}17 \% \text { of newborns had IUGR }(n=2 / 12) \\
\text { metoprolol dose: } 20-120 \mathrm{mg} / \mathrm{day}[23] \\
13.3 \% \text { of }<2,500 \mathrm{~g} \text { newborns }(n=43 / 324)[30] \\
3.1 \% \text { of }<1,500 \mathrm{~g} \text { newborns }(n=10 / 324)[30]\end{array}$ & $\mathrm{C}$ & Yes $[17,58]$ & $\begin{array}{l}\text { PK changes during } \\
\text { pregnancy with need of } \\
\text { aggressive dosage } \\
\text { adaptation [59] } \\
\text { Might be effective in patient } \\
\text { with mutation W305L [60] } \\
\text { Risk of breakthrough CE in } \\
\text { LQTS1/LQTS2 [35] }\end{array}$ \\
\hline \multicolumn{6}{|c|}{ Nonselective $\beta$-receptor blockers } \\
\hline Carvedilol & $\begin{array}{l}\alpha \text { and } \beta \text {-receptor blocking agent } \\
{[61]} \\
\text { Protein binding: }>98 \% \text {, primarily } \\
\text { to albumin }[61] \\
\text { Metabolism: extensively hepatic } \\
\text { [61] } \\
\text { Elimination half-life: adults: } \\
\sim 7-10 \mathrm{~h}[61]\end{array}$ & $\begin{array}{l}7 \% \text { of IUGR was observed }(N=1 / 13) \text {, carvedilol } \\
\text { dose: } 2.5-20 \mathrm{mg} / \text { day }[23]\end{array}$ & $\mathrm{C}$ & $\begin{array}{l}\text { Yes (data } \\
\text { from rats) } \\
\text { [17] }\end{array}$ & $\begin{array}{l}\text { Class III antiarrhythmic } \\
\text { effect might be beneficial } \\
{[62]}\end{array}$ \\
\hline Propranolol & $\begin{array}{l}\beta \text {-1-receptor and } \beta \text {-2-receptor } \\
\text { blockade [63] } \\
\text { Protein binding: newborns: } 68 \% \text {; } \\
\text { adults: } ~ 90 \% \text { [63] } \\
\text { Metabolism: extensively hepatic [63] } \\
\text { Elimination half-life: adults: } \\
\text { Immediate release formulation: } \\
\text { 3-6 h; extended-release } \\
\text { formulations: } 8-10 \mathrm{~h}[63]\end{array}$ & $\begin{array}{l}36 \% \text { of IUGR was observed }(n=8 / 22) \\
\text { propranolol dose: } 15-60 \mathrm{mg} / \text { day }[23] \\
7.6 \% \text { of }<2,500 \mathrm{~g} \text { newborns }(n=37 / 489)[30] \\
1.6 \% \text { of }<1,500 \text { g newborns }(n=8 / 489)[30] \\
29 \% \text { newborns had IUGR }(n=2 / 7)^{3}[29]\end{array}$ & $\mathrm{C}$ & Yes [17] & $\begin{array}{l}\text { Risk for breakthrough CE } \\
\text { in high-risk patients [41] } \\
\text { Efficacy seems comparable } \\
\text { with nadolol (first line) [35, } \\
42,43]\end{array}$ \\
\hline
\end{tabular}


Table 2 (continued)

\begin{tabular}{|c|c|c|c|c|c|}
\hline $\begin{array}{l}\beta \text {-receptor } \\
\text { blocker }\end{array}$ & Pharmacokinetic properties & Data & $\begin{array}{l}\text { Former } \\
\text { FDA } \\
\text { category } \\
{[17]}\end{array}$ & $\begin{array}{l}\text { Placenta } \\
\text { permeable }\end{array}$ & Additional notes \\
\hline Nadolol & $\begin{array}{l}\beta-1 \text { receptor and } \beta-2 \text { receptor } \\
\text { blockade } \\
\text { Protein binding: } 30 \% \text { [64] } \\
\text { Metabolism: not metabolized [64] } \\
\text { Elimination half-life: adults: } 20-24 \\
\text { h (prolonged in case of renal } \\
\text { impairment) [64] }\end{array}$ & $\begin{array}{l}\text { One infant with } 2,675 \mathrm{~g} \text { ( } 7 \text { th percentile), nadolol } \\
\text { dose: } 40-120 \mathrm{mg} / \text { day until gestational week } 12 \text {, } \\
\text { then } 100 \mathrm{mg} / \text { day [22] }\end{array}$ & $\mathrm{C}$ & $\begin{array}{l}\text { Yes [22]; } \\
\text { unknown } \\
{[17]}\end{array}$ & $\begin{array}{l}\text { Effective in LQTS [42-44], } \\
\text { particularly in LQTS2 [41, } \\
65]\end{array}$ \\
\hline
\end{tabular}

IUGR, intrauterine growth retardation; g, gram; PK, pharmacokinetics; CYP, cytochrome P 450 enzymes; v, versus; CE, cardiac events; h, hours; QTc, corrected QT interval; LQTS1, long QT syndrome type 1; LQTS2, long QT syndrome type 2; FDA, Food and Drug Administration. ${ }^{1}$ Mean duration of prenatal drug exposure 13.2 weeks (SD 10.4). ${ }^{2}$ Recruitment took place between 12 and 24 weeks' gestation. ${ }^{3}$ The reported prenatal drug exposure was 27 (+/-15) weeks ( $2 \mathrm{~h}$ to 41 weeks).

diseases, such as (i) congenital heart disease and pulmonary hypertension; (ii) aortic disease; (iii) valvular heart disease; (iv) coronary artery disease and acute coronary syndrome; (v) cardiomyopathy and heart failure; and (vi) arrhythmia, who were exposed to carvedilol ( $n=13$, dose: $2.5-20 \mathrm{mg}$ /day), propranolol $(n=22$, dose: $15-60 \mathrm{mg} /$ day), metoprolol $(n=12$, dose: $20-120 \mathrm{mg} /$ day), atenolol ( $n=6$, dose: $25-50 \mathrm{mg} /$ day), and bisoprolol ( $n=5$, dose: $5-10 \mathrm{mg} /$ day). IUGR occurred in 1 patient (7\%) with carvedilol, in 36\% with propranolol, $17 \%$ with metoprolol, 33\% with atenolol, and in none of the patients treated with bisoprolol $(n=5)$ [23]. Duan et al. [30] analyzed data from 4,847 pregnant women treated with $\beta$-receptor blockers and compared them with data of 374,391 pregnant women without $\beta$-receptor blocker treatment. Diagnoses of hypertension, hyperlipidemia, diabetes, heart failure, and a history of arrhythmia were more common among patients exposed to $\beta$-receptor blockers. The 4 most commonly prescribed $\beta$-receptor blockers were labetalol $(n=3,357)$, atenolol $(n=638)$, propranolol $(n=$ $489)$, and metoprolol $(n=324)$. The risk of fetal growth in infants exposed to metoprolol or propranolol was not significantly different from the nonexposed group (metoprolol: adjusted OR 1.5, 95\% CI 0.9-2.3; propranolol: adjusted OR 1.3, 95\% CI 0.9-1.9), whereas atenolol was associated with an increased risk of IUGR (adjusted OR 2.4, 95\% CI 1.7-3.3) [30]. The mean birth weight and percentage low birth weight $(<2,500 \mathrm{~g})$ were $3,058 \pm 748 \mathrm{~g}$ and $18.0 \%$ for atenolol, $3,163 \pm 702 \mathrm{~g}$ and $13.3 \%$ for metoprolol, 3,286 $\pm 651 \mathrm{~g}$ and $7.6 \%$ for propranolol, and 3,353 \pm $554 \mathrm{~g}$ and $5.2 \%$ for nonexposed controls [30]. Kayser et al. [31] analyzed 294 neonates of hypertensive mothers treated with metoprolol or bisoprolol during the second and/or third trimester and compared these infants with 225 methyldopa-exposed infants and 588 infants of nonhypertensive mothers. The rate of IUGR was significantly higher in infants who had long-term $\beta$-receptor blocker exposure $(24.1 \%)$ as compared to those exposed to methyldopa (10.2\%, OR 2.5, 95\% CI 1.2-5.2) and the non-hypertensive ones (9.9\%, OR 4.3, 95\% CI 2.6-7.1) [31]. Lydakis et al. [27] performed a study in 312 pregnancies of 223 women. Of these pregnancies, $35.9 \%$ were complicated by gestational hypertension, $6.1 \%$ by preeclampsia in previously normotensive women, in $57.4 \%$ of pregnancies there was a positive history of chronic hypertension, and finally $10.9 \%$ of pregnancies had preeclampsia superimposed on chronic hypertension. In 91 of these pregnancies $(29.2 \%)$ no treatment was administered, whereas 78 women were treated with atenolol monotherapy (25\%), 53 with different drugs as antihypertensive monotherapy (17\%), and 90 with multiple drug combinations (28.8\%) [27]. Atenolol was found to be associated with a lower birth weight, a trend towards a higher prevalence of prematurity ( $<37$ weeks) and IUGR as compared to other antihypertensive monotherapies, or to no treatment [27]. Butters et al. [32] treated 15 pregnant women with essential hypertension with atenolol, whereas the other 14 women received placebo. All infants in the atenolol group had a significantly lower birth weight as compared to those in the placebo group $(2,620$ vs. 3,530 g; $910[440-1,380] \mathrm{g})$. They concluded that atenolol given from the end of the first trimester in pregnant women with mild hypertension is associated with IUGR [32]. These observations are in line with Lip at al. 
[33] who showed, by reviewing records of 398 pregnant women, that infants born to women taking atenolol $(n=$ $76)$ had a significantly lower birth weight $(p<0.001)$ than infants born to women taking other $\beta$-blockers, other antihypertensive drugs, or no therapy. Details are shown in Table 2.

\section{$\beta$-Receptor Blockers and Data on Efficacy and iLQTS Type}

The efficacy of $\beta$-receptor blockers seems to be influenced by the genotype [34]. Chockalingam et al. [35] studied ECGs and clinical parameters in 382 LQTS1/ LQTS2 patients treated with propranolol $(n=134$; median dose $1.8 \mathrm{mg} / \mathrm{kg} /$ day), metoprolol ( $n=147$; median dose $0.9 \mathrm{mg} / \mathrm{kg} / \mathrm{day})$, and nadolol $(n=101$, median dose $0.9 \mathrm{mg} / \mathrm{kg} /$ day $)$. The baseline heart rate $(76 \pm 16 \mathrm{bpm})$ was comparable among the different $\beta$-receptor blocker groups, whereas baseline $\mathrm{QT}_{\mathrm{c}}$ was different $(472 \pm 46 \mathrm{~ms}$ ). The on-therapy heart rate and $\mathrm{QT}_{c}$ were different compared to the baseline heart rate and $\mathrm{QT}_{\mathrm{c}}$ within each $\beta$-blocker group, respectively $(p<0.001$ for all paired comparisons). However, while the change in heart rate with $\beta$-receptor blocker initiation was comparable among the groups $(p=0.9)$, the change in $\mathrm{QT}_{\mathrm{c}}$ with propranolol was greater than that with metoprolol $(p=0.003)$ and nadolol $(p=0.004)$. Additionally, the cohort was subdivided in a normal baseline $\mathrm{QT}_{c}(\leq 450 \mathrm{~ms})$, a borderline (451-480 ms), and a prolonged baseline $\mathrm{QT}_{\mathrm{c}}(>480 \mathrm{~ms})$. $\mathrm{The}_{\mathrm{C}} \mathrm{Q}_{\mathrm{c}}$ shortening with propranolol, metoprolol, and nadolol in the normal $\mathrm{QT}_{\mathrm{c}}$ subset and in the borderline $\mathrm{QT}_{\mathrm{c}}$ subset was comparable, but was significantly different in the prolonged $\mathrm{QT}_{\mathrm{c}}$ subset $(49 \pm 42,30 \pm 40,27 \pm 29$ $\mathrm{ms}, p=0.01$ ). They concluded that propranolol had a significantly better $\mathrm{QT}_{\mathrm{c}}$ shortening effect compared to metoprolol and nadolol, particularly in patients with prolonged $\mathrm{QT}_{\mathrm{c}}$ [35]. As Kaplan-Meier analysis showed a significantly lower event-free survival for symptomatic patients on metoprolol compared to nadolol/propranolol, they stated that metoprolol should not be used in symptomatic LQTS1/LQTS2 patients, whereas propranolol and nadolol seem equally effective [35]. However, the $\mathrm{QT}_{\mathrm{c}}$ shortening effect of propranolol seems to be dose dependent, as particularly high concentrations result in a significant shortening of the $\mathrm{QT}_{\mathrm{c}}$ interval $[36,37]$. Chatrath at al. [38] studied 28 patients with iLQTS treated with atenolol $(n=12)$, propranolol $(n=10)$, metoprolol $(n=4)$, and nadolol $(n=2)$ for breakthrough CE. During a median follow-up of 46 months, 7 patients (25\%) developed 15 breakthrough CE. Of these, 10 occurred in atenolol and 3 in propranolol compliant patients; 2 were

IUGR in Pregnant LQTS Women Treated with $\beta$-Receptor Blockers related with noncompliance. They concluded that atenolol treatment might be an important factor for breakthrough CE [38]. Fazio et al. [39] evaluated 34 LQTS patients with an average follow-up time of 93 months for (i) no treatment (31 months), (ii) treatment with nadolol or propranolol (31 months), and (iii) treatment with bisoprolol (31 months). They observed in the follow-up period 2 major (arrhythmic syncope resuscitated by electrical defibrillation) and 12 minor (non-arrhythmic syncope \pm loss of consciousness) CEs. Both major events occurred without $\beta$-receptor blocker treatment, whereas the minor events were distributed as follows: 3 without treatment, 2 with nadolol, 5 with propranolol, and 2 with bisoprolol [39]. Steinberg et al. [40] compared retrospectively ECG parameters and CE of 114 LQTS1/LQTS2-patients treated with bisoprolol $(n=59)$, nadolol $(n=16)$, or atenolol $(n=39)$. The baseline heart rate and $\mathrm{QT}_{\mathrm{c}}$ interval were similar between the groups. $\mathrm{QT}_{\mathrm{c}}$ shortening was observed in the individuals on bisoprolol $\left(\Delta \mathrm{QT}_{\mathrm{c}}-5\right.$ $\pm 31 \mathrm{~ms} ; p=0.049)$ and nadolol $\left(\Delta \mathrm{QT}_{\mathrm{c}}-13 \pm 16 \mathrm{~ms} ; p=\right.$ $0.02)$, but not on atenolol $\left(\Delta \mathrm{QT}_{\mathrm{c}}+9 \pm 24 \mathrm{~ms} ; p=0.16\right)$ [40]. A median follow-up was 3 years for bisoprolol and nadolol and 6 years for atenolol [40]. During follow-up, one $\mathrm{CE}$ was observed in the bisoprolol group (1.7\%) and 2 for the atenolol group (5.1\%; $p=0.45)$, none occurred in nadolol treated patients. Based on that, they pointed out, that bisoprolol is effective in $\mathrm{QT}_{\mathrm{c}}$ shortening for LQTS1 and LQTS2 and is well tolerated during long-term administration [40]. Abu-Zeitone compared in 1,530 patients from the Rochester, New York-based LQTS registry, the efficacy of nadolol $(n=259$; dose: $<18$ and $\geq 18$ years: $1.0 \pm 0.8 \mathrm{mg} / \mathrm{kg} /$ day), propranolol ( $n=679$; dose: $<18$ years: $2.3 \pm 1.5 \mathrm{mg} / \mathrm{kg} /$ day, $\geq 18$ years: $2.1 \pm 2.3 \mathrm{mg} /$ $\mathrm{kg} /$ day), atenolol ( $n=441$; dose: $<18$ years: $1.0 \pm 0.7 \mathrm{mg} /$ $\mathrm{kg} /$ day, $\geq 18$ years: $0.7 \pm 0.3 \mathrm{mg} / \mathrm{kg} /$ day), and metoprolol ( $n=151$; dose: $<18$ years: $1.4 \pm 1.0 \mathrm{mg} / \mathrm{kg} / \mathrm{day}, \geq 18$ years: $1.2 \pm 0.9 \mathrm{mg} / \mathrm{kg} /$ day) in LQTS and in genotype positive patients with LQTS1/LQTS2 [41]. In LQTS1 $(n=379)$, the risk reduction for any $\beta$-receptor blocker was $57 \%$ $(p<0.01)$ with insufficient evidence of different efficacy for any specific drug. In LQTS2 $(n=406)$ there was a significant variability in efficacy by drug, with nadolol being the only $\beta$-receptor blocker showing a significant risk reduction in CE (hazard ratio $0.40 ; p<0.05$ ). The authors concluded that nadolol is the only $\beta$-receptor blocker with a significant risk reduction in LQTS2 patients [41]. Recurrent CE occurred less frequently in patients with initially prescribed metoprolol, nadolol, and atenolol compared with propranolol $(p=0.002)$ [41]. Schwartz recommends that initial treatment of iLQTS should al- 
ways involve $\beta$-receptor blockers, with propranolol and nadolol being the 2 most effective ones, whereas bisoprolol, metoprolol, atenolol, and carvedilol being less effective [42]. Similarly, Ackermann et al. [43], highlighted recently that the protective effect of the nonselective $\beta$-receptor blockers nadolol and propranolol in management of iLQTS is superior than that observed with $\beta$-1selective receptor blockers. They report that there is substantial consensus among experts to prefer nadolol as a first-choice treatment in patients with iLQTS [43]. In line with these suggestions is the observation from Mazzanti et al. [44], showing the superiority of nadolol in risk reduction of CEs for iLQTS patients.

\section{Discussion}

$\beta$-receptor blockers are effective in reducing lifethreatening CE in iLQTS and therefore should be continued during pregnancy and postpartum as pregnant iLQTS women are at a risk to develop CE $[8-10,17,45]$. $\beta$-receptor blockers are not teratogenic, but they are categorized by former FDA category as " $\mathrm{C}$," whereas atenolol is categorized as "D." They can cause IUGR commonly and additionally bradycardia, apnea, hypoglycemia, and hyperbilirubinemia have been reported in the newborn infant [17-20]. Pregnant iLQTS women are not only at a risk for IUGR due to $\beta$-receptor blocker treatment, but also due to their underlying disease. IUGR can result in adverse neonatal outcomes. Fetuses with IUGR are at a risk for preterm delivery and they have a higher risk of mortality and perinatal complications [46]. Long-term outcome can be affected by an increased risk for neurodevelopmental impairment and growth delay [46]. Treatment recommendations for pregnant iLQTS women and data on IUGR in infants exposed prenatally to $\beta$-receptor blockers are scarce. LQTS management in pregnant women is challenging, as several factors addressing the fetus, such as IUGR and the mother, such as efficacy of the $\beta$-receptor blocker treatment, have to be taken into account.

Data on the efficacy of $\beta$-receptor blockers are heterogeneous but several studies and experts state that nonselective $\beta$-receptor blockers, such as nadolol and propranolol, might be superior in iLQTS management, particularly in patients with LQTS2 [35, 41-43]. Nadolol is approved by the FDA. Unfortunately, nadolol is not available in all European countries. Study data on prenatal nadolol exposure and IUGR are scarce. Nadolol has a 30\% protein binding and a long half-life with a risk of causing adverse events in the newborn still several hours after birth [22]. The longer duration of action and its protein binding seems to make it less desirable for use in pregnancy [47]. Propranolol and nadolol, both nonselective $\beta$-receptor blockers, seem not to be the recommended first choice in general in pregnant women. However, if a woman with iLQTS was treated with nadolol effectively before becoming pregnant or if a LQTS2 genotype is known, continuation of the treatment with nadolol or start of nadolol should be considered. During our literature search we could identify most data related to IUGR for the $\beta$-1-selective receptor blocker atenolol. All available studies highlighted a negative impact on fetal growth, and therefore atenolol should be avoided in pregnancy. The other $\beta$-1-selective receptor blockers seem to affect less likely the uterine contraction and peripheral vasodilation and have therefore a lower rate of IUGR [17]. Based on the very limited data with respect to the current recommendation to favor in general $\beta$-1-selective receptor blockers in pregnancy there might be an indication that bisoprolol is the one with a relatively low risk for IUGR. We have to emphasize that only scarce data are available for bisoprolol and IUGR $(n=5)$ and that data on the efficacy of bisoprolol in LQTS1/LQTS2 are limited, although, available studies show good and comparable efficacy to nadolol/propranolol in preventing major $\mathrm{CE}$ and well tolerated long-term tolerance $[23,39,40]$. Based on the fact that there are so few data available, we are not able to recommend the optimal choice of a $\beta$-receptor blocker for use in pregnant iLQTS women. For a personalized $\beta$-receptor blocker treatment, it is important, that each woman diagnosed with iLQTS who wants to become pregnant should be consulted by a multidisciplinary team consisting of cardiologists, gynecologists, pediatric cardiologists, neonatologists, and clinical pharmacologists. This team should evaluate the current medication for individual risks in respect to mother and fetus, underlying comorbidities of the mother, the iLQTS genotype, the pharmacologic $\beta$-receptor blocker properties, and riskbenefit assessment in case of a $\beta$-receptor blocker switch. Desirable drug properties in pregnancy due to reduced maternal-fetal exchange are, for example, a low lipophilicity, an intrinsic sympathomimetic activity, a high protein binding, and a large molecular weight $[23,48]$. If the multidisciplinary team considers a $\beta$-receptor blocker switch (i) a wearable cardioverter defibrillator or (ii) an inpatient monitoring might be beneficial during the period of up-titration, which might be associated with a higher risk for CE. Irrespective of $\beta$-receptor blocker selection, each pregnant iLQTS women treated with a 
$\beta$-receptor blocker should be monitored regularly for fetal growth. It seems that pregnancy associated plasma protein, regular uterine artery Doppler, serial fundal height measurements, and middle cerebral artery Doppler are useful to early detect IUGR $[49,50]$. Additionally, it is recommended to determine the time of delivery guided by umbilical artery and ductus venosus blood flow patterns [17]. After delivery, each infant who was prenatally exposed to a $\beta$-receptor blocker should be monitored for bradycardia, hypoglycemia, and respiratory depression, preferentially if possible in a neonatal care unit. Assuming linear pharmacokinetics for these $\beta$-receptor blockers, $95 \%$ will be eliminated after 5 times of their half-lives (Table 2) resulting in the following elimination time periods: (i) metoprolol after $25-50 \mathrm{~h}$, (ii) propranolol after 15-50 h, (iii) carvedilol after 35-50 h, (iv) bisoprolol after 45-60 h, and for (v) nadolol in 100-120 h. Embryotox (www.embryotox.de) stated for bisoprolol, metoprolol, propranolol, and carvedilol that beta-receptor blockerrelated side effects should improve in the infant $48 \mathrm{~h}$ after delivery [51].

There are several limitations of this review. Despite the fact that we used a comprehensive search strategy to identify relevant publications there is the risk of reporting bias as we might have missed some articles by our defined search strings and the fact that we have not performed a systematic review. Several studies were retrospective cohort studies, and both the underlying disease and the $\beta$-receptor blocker might have had a combined effect on IUGR. In addition, the majority of data on IUGR exposed infants is collected from pregnant women with hypertension and not from iLQTS patients. Furthermore, we cannot recommend a first-line $\beta$-receptor blocker treatment for pregnant iLQTS patients because in addition to IUGR other maternal and fetal factors have to be taken into account. We have summarized these factors to assist treating physicians in making the optimal choice for each individual pregnant woman with iLQTS.

\section{Conclusion}

Pregnant women with iLQTS are at an increased risk for postpartum CE and should be treated with $\beta$-receptor blockers during pregnancy and the postpartum period. In general, different $\beta$-receptor blockers can be used safely and are recommended in pregnancy, except atenolol. Nadolol and propranolol seem to be superior in efficacy as compared to $\beta$-1-selective receptor blockers, particularly in LQTS2. $\beta$-1-selective receptor blockers seem to be

associated with a lower risk of uterine contraction, peripheral vasodilation, fetal hypoglycemia, and IUGR. It is important that each woman diagnosed with iLQTS who wants to become pregnant should be evaluated for individual risks, underlying comorbidities, and iLQTS genotype. A multidisciplinary team consisting of cardiologists, gynecologists, pediatric cardiologists, neonatologists, and clinical pharmacologists should recommend a personalized $\beta$-receptor blocker treatment in respect to iLQTS genotype as soon as possible. Furthermore, a close monitoring of the fetal growth is mandatory during pregnancy. After delivery, each infant who was prenatally exposed to a $\beta$-receptor blocker should be monitored for bradycardia, hypoglycemia, and respiratory depression for 2-3 days (nadolol up to 5 days).

\section{Conflict of Interest Statement}

The authors have no conflicts of interest to declare.

\section{Funding Sources}

The authors confirm that the work received no funding.

\section{Author Contributions}

Conceptualization, T.W., B.D., and J.N.v.d.A.; data curation, T.W.; writing - original draft preparation, T.W.; writing - review and editing, B.D. and J.N.v.d.A.; supervision, B.D. and J.N.v.d.A.

References

Neonatology 2021;118:406-415 DOI: $10.1159 / 000516845$
1 Elkayam U, Goland S, Pieper PG, Silverside CK. High-risk cardiac disease in pregnancy: part I. J Am Coll Cardiol. 2016;68(4):396410.

2 Barsheshet A, Dotsenko O, Goldenberg I. Congenital long QT syndromes: prevalence, pathophysiology and management. Paediatr Drugs. 2014;16(6):447-56.

3 Priori SG, Blomstrom-Lundqvist C, Mazzanti A, Blom N, Borggrefe M, Camm J, et al. 2015 ESC Guidelines for the management of patients with ventricular arrhythmias and the prevention of sudden cardiac death: the task force for the management of patients with ventricular arrhythmias and the prevention of sudden cardiac death of the European Society of Cardiology (ESC). Endorsed by: Association for European Paediatric and Congenital Cardiology (AEPC). Eur Heart J. 2015;36(41): 2793-867.

4 Schwartz PJ, Crotti L. QTc behavior during exercise and genetic testing for the long-QT syndrome. Circulation. 2011;124(20):2181-4. 
5 Cantwell R, Clutton-Brock T, Cooper G, Dawson A, Drife J, Garrod D, et al. Saving mothers' lives: reviewing maternal deaths to make motherhood safer: 2006-2008. The eighth report of the confidential enquiries into maternal deaths in the United Kingdom. BJOG. 2011;118(Suppl 1):1-203.

6 Cuneo BF, Kaizer AM, Clur SA, Swan H, Herberg U, Winbo A, et al. Mothers with long QT syndrome are at increased risk for fetal death: findings from a multicenter international study. Am J Obstet Gynecol. 2020;222(3): 263-e11.

7 Crotti L, Tester DJ, White WM, Bartos DC, Insolia R, Besana A, et al. Long QT syndromeassociated mutations in intrauterine fetal death. JAMA. 2013;309(14):1473-82.

8 Garg L, Garg J, Krishnamoorthy P, Ahnert A, Shah N, Dusaj RS, et al. Influence of pregnancy in patients with congenital long QT syndrome. Cardiol Rev. 2017;25(4):197-201.

9 Rashba EJ, Zareba W, Moss AJ, Hall WJ, Robinson J, Locati EH, et al. Influence of pregnancy on the risk for cardiac events in patients with hereditary long QT syndrome. LQTS Investigators. Circulation. 1998;97(5):451-6.

10 Seth R, Moss AJ, McNitt S, Zareba W, Andrews ML, Qi M, et al. Long QT syndrome and pregnancy. J Am Coll Cardiol. 2007; 49(10):1092-8.

11 Khositseth A, Tester DJ, Will ML, Bell CM, Ackerman MJ. Identification of a common genetic substrate underlying postpartum cardiac events in congenital long QT syndrome. Heart Rhythm. 2004;1(1):60-4.

12 Schwartz PJ, Priori SG, Spazzolini C, Moss AJ, Vincent GM, Napolitano C, et al. Genotypephenotype correlation in the long-QT syndrome: gene-specific triggers for life-threatening arrhythmias. Circulation. 2001;103(1):89-95.

13 Nakajima T, Iwasawa K, Oonuma H, Morita T, Goto A, Wang Y, et al. Antiarrhythmic effect and its underlying ionic mechanism of 17beta-estradiol in cardiac myocytes. $\mathrm{Br} \mathrm{J}$ Pharmacol. 1999;127(2):429-40.

14 Kam KW, Qi JS, Chen M, Wong TM. Estrogen reduces cardiac injury and expression of beta1-adrenoceptor upon ischemic insult in the rat heart. J Pharmacol Exp Ther. 2004; 309(1):8-15.

15 Ahn J, Kim HJ, Choi JI, Lee KN, Shim J, Ahn HS, et al. Effectiveness of $\beta$-blockers depending on the genotype of congenital long-QT syndrome: a meta-analysis. PLoS One. 2017; 12(10): 0185680

16 Goldenberg I, Bradley J, Moss A, McNitt S, Polonsky S, Robinson JL, et al. $\beta$-blocker efficacy in high-risk patients with the congenital long-QT syndrome types 1 and 2: implications for patient management. J Cardiovasc Electrophysiol. 2010;21(8):893-901.

17 Regitz-Zagrosek V, Roos-Hesselink JW, Bauersachs J, Blomström-Lundqvist C, Cífková R, De Bonis M, et al. 2018 ESC guidelines for the management of cardiovascular diseases during pregnancy. Eur Heart J. 2018;39(34): 3165-241.
18 Cox JL, Gardner MJ. Treatment of cardiac arrhythmias during pregnancy. Prog Cardiovasc Dis. 1993;36(2):137-78.

19 Chow T, Galvin J, McGovern B. Antiarrhythmic drug therapy in pregnancy and lactation. Am J Cardiol. 1998;82(4A):58I-62I.

20 Meidahl Petersen K, Jimenez-Solem E, Andersen JT, Petersen M, Brodbaek K, Kober L, et al. $\beta$-blocker treatment during pregnancy and adverse pregnancy outcomes: a nationwide population-based cohort study. BMJ Open. 2012;2(4):e001185.

21 Horigome H, Nagashima M, Sumitomo N, Yoshinaga $M$, Ushinohama $H$, Iwamoto $M$, et al. Clinical characteristics and genetic background of congenital long-QT syndrome diagnosed in fetal, neonatal, and infantile life: a nationwide questionnaire survey in Japan. Circ Arrhythm Electrophysiol. 2010;3(1): 10-7.

22 King-Mallory RB, Shawndra, McGrogan K, Franks, Adam M. Nadolol in pregnancy: a medical student's reflection on her pregnancy. Marshall J Med. 2018;4(4).

23 Tanaka K, Tanaka H, Kamiya C, Katsuragi S, Sawada M, Tsuritani M, et al. $\beta$-blockers and fetal growth restriction in pregnant women with cardiovascular disease. Circ J. 2016; 80(10):2221-6.

24 Ersboll AS, Hedegaard M, Sondergaard L, Ersboll M, Johansen M. Treatment with oral $\beta$-blockers during pregnancy complicated by maternal heart disease increases the risk of fetal growth restriction. BJOG. 2014;121(5): 618-26.

25 Karlsson K, Lundgren Y, Ljungblad U. The acute effects of a non-selective $\beta$-adrenergic blocking agent in hypertensive pregnant rats. Acta Obstet Gynecol Scand Suppl. 1984;118: 81-4.

26 Harbert GM Jr, Spisso KR. Effect of adrenergic blockade on dynamics of the pregnant primate uterus (Macaca mulatta). Am J Obstet Gynecol. 1981;139(7):767-80.

27 Lydakis C, Lip GY, Beevers M, Beevers DG. Atenolol and fetal growth in pregnancies complicated by hypertension. Am J Hypertens. 1999;12(6):541-7.

28 Nakhai-Pour HR, Rey E, Bérard A. Antihypertensive medication use during pregnancy and the risk of major congenital malformations or small-for-gestational-age newborns. Birth Defects Res B Dev Reprod Toxicol. 2010;89(2):147-54

29 Cissoko H, Jonville-Béra AP, Swortfiguer D, Giraudeau B, Autret-Leca E. [Neonatal outcome after exposure to beta adrenergic blockers late in pregnancy]. Arch Pediatr. 2005; 12(5):543-7.

30 Duan L, Ng A, Chen W, Spencer HT, Lee MS. $\beta$-blocker subtypes and risk of low birth weight in newborns. J Clin Hypertens. 2018; 20(11):1603-9.

31 Kayser A, Beck E, Hoeltzenbein M, Zinke S, Meister R, Weber-Schoendorfer C, et al. Neonatal effects of intrauterine metoprolol/bisoprolol exposure during the second and third trimester: a cohort study with two comparison groups. J Hypertens. 2020;38(2):354-61.

32 Butters L, Kennedy S, Rubin PC. Atenolol in essential hypertension during pregnancy. BMJ. 1990;301(6752):587-9.

33 Lip GY, Beevers M, Churchill D, Shaffer LM, Beevers DG. Effect of atenolol on birth weight. Am J Cardiol. 1997;79(10):1436-8.

34 Saadeh K, Shivkumar K, Jeevaratnam K. Targeting the $\beta$-adrenergic receptor in the clinical management of congenital long QT syndrome. Ann N Y Acad Sci. 2020;1474(1):2746.

35 Chockalingam P, Crotti L, Girardengo G, Johnson JN, Harris KM, van der Heijden JF, et al. Not all $\beta$-blockers are equal in the management of long QT syndrome types 1 and 2: higher recurrence of events under metoprolol. J Am Coll Cardiol. 2012;60(20):2092-9.

36 Duff HJ, Mitchell LB, Wyse DG. Antiarrhythmic efficacy of propranolol: comparison of low and high serum concentrations. J Am Coll Cardiol. 1986;8(4):959-65.

37 Duff HJ, Roden DM, Brorson L, Wood AJ, Dawson AK, Primm RK, et al. Electrophysiologic actions of high plasma concentrations of propranolol in human subjects. J Am Coll Cardiol. 1983;2(6):1134-40.

38 Chatrath R, Bell CM, Ackerman MJ. $\beta$-blocker therapy failures in symptomatic probands with genotyped long-QT syndrome. Pediatr Cardiol. 2004;25(5):459-65.

39 Fazio G, Vernuccio F, Lo Re G, Grutta G, Mongiovì $\mathrm{M}$. Role of bisoprolol in patients with long QT syndrome. Ann Noninvasive Electrocardiol. 2013;18(5):467-70.

40 Steinberg C, Padfield GJ, Al-Sabeq B, Adler A, Yeung-Lai-Wah JA, Kerr CR, et al. Experience with bisoprolol in long-QT1 and longQT2 syndrome. J Interv Card Electrophysiol. 2016;47(2):163-70.

41 Abu-Zeitone A, Peterson DR, Polonsky B, McNitt S, Moss AJ. Efficacy of different $\beta$-blockers in the treatment of long QT syndrome. J Am Coll Cardiol. 2014;64(13): $1352-8$

42 Schwartz PJ. Pharmacological and non-pharmacological management of the congenital long QT syndrome: the rationale. Pharmacol Ther. 2011;131(1):171-7.

43 Ackerman MJ, Priori SG, Dubin AM, Kowey $P$, Linker NJ, Slotwiner D, et al. $\beta$-blocker therapy for long QT syndrome and catecholaminergic polymorphic ventricular tachycardia: are all beta-blockers equivalent? Heart Rhythm. 2017;14(1):e41-e4.

44 Mazzanti A, Maragna R, Vacanti G, Monteforte N, Bloise R, Marino M, et al. Interplay between genetic substrate, QTc duration, and arrhythmia risk in patients with long QT syndrome. J Am Coll Cardiol. 2018;71(15):166371.

45 Ishibashi K, Aiba T, Kamiya C, Miyazaki A, Sakaguchi H, Wada M, et al. Arrhythmia risk and $\beta$-blocker therapy in pregnant women with long QT syndrome. Heart. 2017;103(17): 1374-9. 
46 von Beckerath AK, Kollmann M, Rotky-Fast C, Karpf E, Lang U, Klaritsch P. Perinatal complications and long-term neurodevelopmental outcome of infants with intrauterine growth restriction. Am J Obstet Gynecol. 2013;208(2):130-6.

47 Fox RE, Marx C, Stark AR. Neonatal effects of maternal nadolol therapy. Am J Obstet Gynecol. 1985;152(8):1045-6.

48 Nauheimer D. Medikamente in der Schwangerschaft: Welche Substanzen eignen sich im Akutfall? Lege Artis. 2012;2(05): 312-9.

49 McCowan LM, Figueras F, Anderson NH. Evidence-based national guidelines for the management of suspected fetal growth restriction: comparison, consensus, and controversy. Am J Obstet Gynecol. 2018;218(2S):S855-S68.

50 Kirkegaard I, Henriksen TB, Uldbjerg N. Early fetal growth, PAPP-A and free $\beta$-hCG in relation to risk of delivering a small-for-gestational age infant. Ultrasound Obstet Gynecol. 2011;37(3):341-7.

51 Pharmakovigilanz- und Beratungszentrum für Embryonaltoxikologie. Berlin. Available from: www.embryotox.de Last Accessed on 2021 Mar 28.

52 Pernia S, DeMaagd G. The new pregnancy and lactation labeling rule. P T. 2016;41(11): $713-5$.
53 Atenolol: Drug information. Retrieved 2020 Oct 2 from UpToDate database. Available from: https://www.uptodate.com/contents/ atenolol-drug-information.

54 Rubin PC, Butters L, Reynolds B, Evans J, Sumner D, Low RA, et al. Atenolol elimination in the neonate. Br J Clin Pharmacol. 1983;16(6):659-62

55 Bayliss H, Churchill D, Beevers M, Beevers DG. Anti-hypertensive drugs in pregnancy and fetal growth: evidence for "pharmacological programming" in the first trimester? Hypertens Pregnancy. 2002;21(2):161-74.

56 Bisoprolol: Drug information. Retrieved 2020 Oct 2 from UpToDate database. Available from: https://www.uptodate.com/contents/ bisoprolol-drug-information.

57 Metoprolol: Drug information. Retrieved 2020 Oct 2 from UpToDate database. Available from: https://www.uptodate.com/contents/metoprolol-drug-information.

58 Lindeberg S, Lundborg P, Regårdh CG, Sandström B. Disposition of the adrenergic blocker metoprolol and its metabolite $\mathrm{OH}$-metoprolol in maternal plasma, amniotic fluid and capillary blood of the neonate. Eur J Clin Pharmacol. 1987;33(4):363-8.

59 Ryu RJ, Eyal S, Easterling TR, Caritis SN, Venkataraman R, Hankins G, et al. Pharmacokinetics of metoprolol during pregnancy and lactation. J Clin Pharmacol. 2016;56(5): 581-9.
60 Zhou H, Lai W, Zhu W, Xie J, Liu X, Shen Y, et al. Genotype-based clinical manifestation and treatment of Chinese long QT syndrome patients with KCNQ1 mutations: R380S and W305L. Cardiol Young. 2016;26(4):754-63.

61 Carvedilol: Drug information. Retrieved 2020 Oct 2 from UpToDate database. Available from: https://www.uptodate.com/contents/ carvedilol-drug-information.

62 Kawakami K, Nagatomo T, Abe H, Kikuchi K, Takemasa $\mathrm{H}$, Anson BD, et al. Comparison of HERG channel blocking effects of various $\beta$-blockers: implication for clinical strategy. Br J Pharmacol. 2006;147(6):642-52.

63 Propranolol: Drug information. Retrieved 2020 Oct 2 from UpToDate database. Available from: https://www.uptodate.com/contents/propranolol.

64 Nadolol: Drug information. Retrieved 2020 Oct 2 from UpToDate database. Available from: https://www.uptodate.com/contents/ nadolol-drug-information.

65 Han L, Liu F, Li Q, Qing T, Zhai Z, Xia Z, et al. The efficacy of $\beta$-blockers in patients with long QT syndrome 1-3 according to individuals' gender, age, and QTc intervals: a network meta-analysis. Front Pharmacol. 2020; 11:579525. 